\title{
Faktor-Faktor yang Mempengaruhi Kepatuhan Peserta Mandiri Dalam Pembayaran Iuran Program Jaminan Kesehatan Nasional di Kota Solok
}

\author{
Ayu Wulandari ${ }^{1}$, Nur Afrainin Syah ${ }^{2}, \mathrm{CH}$. Tuty Ernawati ${ }^{3}$
}

\begin{abstract}
Abstrak
Kepatuhan peserta mandiri membayar iuran Jaminan Kesehatan Nasional (JKN) di Kota Solok belum maksimal. Hal ini terlihat dari jumlah peserta mandiri yang menunggak di Kota Solok yaitu $69 \%$ dari peserta mandiri terdaftar. Tujuan: Mengidentifikasi faktor-faktor yang mempengaruhi kepatuhan peserta mandiri dalam pembayaran iuran Program JKN di Kota Solok. Metode: Penelitian ini menggunakan rancangan cross sectional, dengan sampel penelitian adalah peserta mandiri program JKN di Kota Solok yang terpilih secara acak. Analisis data dilakukan dengan uji Chi-square. Responden dalam penelitian ini adalah 105 orang peserta mandiri yang minimal berusia 17 tahun dan berdomisili di Kota Solok. Hasil: Uji statistik menunjukkan terdapat hubungan yang signifikan antara tingkat pengetahuan $(p=0,019)$, pendapatan $(p=0,038)$, persepsi terhadap pelayanan kesehatan $(p=0,047)$ dan persepsi terhadap risiko $(p=0,043)$ dengan kepatuhan pembayaran iuran peserta mandiri program JKN BPJS Kesehatan di Kota Solok. Simpulan: Tidak terdapat hubungan signifikan antara tingkat pendidikan, jarak tempuh tempat pembayaran iuran dan jumlah tanggungan terhadap kepatuhan pembayaran iuran peserta mandiri program JKN BPJS Kesehatan di Kota Solok. BPJS Kesehatan Cabang Solok harus meningkatkan kuantitas dan kualitas sosialisasi untuk meningkatkan pengetahuan peserta tentang hak dan kewajiban peserta mandiri program JKN.
\end{abstract}

Kata kunci: kepatuhan, luran JKN, BPJS Kesehatan

\begin{abstract}
The obedience of an independent participant pays national health insurance JKN fee in Solok have not been maximal yet. It can be seen due to the number of independent participants. There were $69 \%$ from the list who still owes its fee. Objectives: To identified the factors that affect the obedience of an independent participant in the paying fee of JKN program in Solok. Methods: It was a cross sectional study and the sample in this research was the independent participant of JKN program in Solok that selected randomly. Then, the data were analyzed by the Chisquare test. The respondence were 105 independent participants who were at least 17 years old and stayed in Solok downtown. Results: Statistical results indicate that there was a significant correlation between the level of knowledge $(p=0.019)$, income $(p=0.038)$, perception of health care $(p=0.047)$ and understanding of risk $(p=0.043)$ by obedience to the payment fee of independent participants in JKN BPJS health program. Conclusion: There is no significant correlation between education level, distance of the place to pay tax, and amount of charge with the obedience of those participants. Health of BPJS in the Solok branch must increase the quantity and quality counseling to improve their knowledge of incumbency toward JKN program.
\end{abstract}

Keywords: compliance; JKN contribution; BPJS Kesehatan

Affiliasi penulis: ${ }^{1}$ BPJS Ketenagakerjaan Tanjung Morawa, ${ }^{2}$ Bagian Anatomi, Fakultas Kedokteran, Universitas Andalas, Padang, ${ }^{3}$ Fakultas Kesehatan Masyarakat, Universitas Andalas, Padang
Korespondensi: Nur Afrainin Syah, Ayu Wulandari, Email: drnurafrainin@yhaoo.co.uk, ayuwulandariskm@gmail.com Telp: 08116676901 


\section{PENDAHULUAN}

Kesehatan merupakan hak asasi manusia dan merupakan salah satu unsur kesejahteraan yang harus diwujudkan bagi segenap bangsa Indonesia. Menurut Undang-Undang Nomor 36 Tahun 2009 ditegaskan bahwa setiap orang mempunyai hak yang sama dalam memperoleh akses atas sumber daya di bidang kesehatan dan memperoleh pelayanan kesehatan yang aman, bermutu, dan terjangkau. Sebaliknya, setiap orang juga mempunyai kewajiban turut serta dalam program jaminan sosial. ${ }^{1}$

Pemerintah telah mengupayakan berbagai kebijakan untuk mewujudkan peningkatan derajat kesehatan masyarakat yang dilaksanakan berdasarkan prinsip non diskriminatif, partisipatif, dan berkelanjutan. Kebijakan yang mengatur hak atas jaminan sosial untuk dapat memenuhi kebutuhan hidup dasar yang layak dan menyeluruh tercantum dalam Undang-Undang Nomor 40 Tahun 2004 tentang Sistem Jaminan Sosial Nasional (SJSN). Pelaksanaan SJSN dilakukan oleh suatu badan hukum pengelola jaminan sosial yang selanjutnya disebut Badan Penyelenggara Jaminan Sosial (BPJS). Dalam penyelenggaraannya BPJS terbagi menjadi dua yaitu BPJS Ketenagakerjaan dan BPJS Kesehatan. BPJS Ketenagakerjaan memiliki 4 (empat) program jaminan yaitu jaminan kecelakaan kerja, jaminan kematian, jaminan hari tua dan jaminan pensiun, sedangkan BPJS Kesehatan hanya memiliki 1 (satu) program jaminan yaitu jaminan kesehatan yang disebut dengan Jaminan Kesehatan Nasional. ${ }^{2}$

Program Jaminan Kesehatan Nasional (JKN) melalui BPJS Kesehatan merupakan inisiatif untuk pemerataan kualitas layanan kesehatan bagi seluruh lapisan masyarakat, dengan iuran yang terjangkau dan cakupan pelayanan kesehatan yang luas. Iuran adalah sejumlah uang yang dibayar secara teratur oleh peserta, pemberi kerja, dan/atau pemerintah. luran merupakan faktor esensial dalam suksesnya suatu sistem jaminan sosial nasional. luran peserta mandiri bervariasi sesuai kelas dan tingkat kemampuan masyarakat. Kesinambungan masyarakat dalam membayar iuran secara rutin berdampak pada pendanaan sistem jaminan kesehatan nasional. Tanpa pembayaran iuran secara berkesinambungan dapat mengakibatkan penyelenggaraan JKN berjalan tidak baik. Sehingga, peserta mandiri JKN harus proaktif secara rutin dalam membayar iuran. ${ }^{3}$

Peningkatan jumlah peserta menjadi salah satu indikator bahwa program JKN semakin dibutuhkan masyarakat. Berdasarkan laporan cakupan kepesertaan BPJS Kesehatan bulan Desember 2016, jumlah peserta yang terdaftar yaitu 171.939.254 jiwa. Mengingat pentingnya program JKN, maka semua pihak dituntut aktif menjaga agar program untuk dapat berjalan secara berkelanjutan. Salah satu upaya yang bisa dilakukan peserta untuk menjaga keberlangsungan program JKN yaitu rutin membayar iuran. ${ }^{4}$

Berdasarkan laporan dari BPJS Kesehatan pada tahun 2016, secara nasional jumlah masyarakat Indonesia yang telah menjadi Peserta Program JKN berjumlah 171.939.254 jiwa. Peserta ini terdiri dari beberapa jenis kepesertaan diantaranya peserta bukan penerima bantuan iuran dan peserta penerima bantuan iuran. Peserta mandiri merupakan jumlah peserta terbanyak kedua yaitu $11 \%$ setelah Peserta Penerima Bantuan luran (PBI) APBN/ Jamkesmas sebanyak $52 \%$. Peserta lain yaitu pegawai swasta sejumlah 9\%, Peserta Jaminan Kesehatan Daerah (Jamkesda) sebanyak $8 \%$, pegawai BUMD sebanyak $8 \%$, Pegawai Negeri Sipil (PNS) sebanyak 6\%, pensiunan sebanyak $3 \%$, Tentara Negara Indonesia (TNI) sebanyak $1 \%$, POLRI sebanyak $1 \%$, dan pegawai BUMN sebanyak $1 \% .^{5}$

Masyarakat yang telah menjadi Peserta JKN pada tahun 2016 di Sumatera Barat berjumlah 3.737.921 jiwa. Peserta mandiri merupakan jumlah peserta terbanyak ketiga yaitu $15 \%$, setelah Peserta PBI APBN/ Jamkesmas sebanyak 43\% dan Jamkesda sebanyak $16 \%$. Peserta lainnya yaitu PNS sebanyak $13 \%$, pegawai swasta sejumlah $7 \%$, pensiunan sebanyak $4 \%$, TNI dan POLRI sebanyak $1 \%$, pegawai BUMN sebanyak 0,5\%, dan pegawai BUMD sebanyak $0,5 \% .^{5}$

Kota Solok memiliki peserta JKN pada tahun 2016 sejumlah 55.462 jiwa. Peserta mandiri merupakan peserta terbanyak keempat yaitu 13\% setelah PBI APBN/ Jamkesmas sebanyak 22\%, Jamkesda sebanyak $20 \%$, dan PNS sebanyak $18 \%$. 
Peserta lainnya terdiri dari pegawai swasta sejumlah $9 \%$, pegawai BUMD sebanyak $9 \%$, pensiunan sebanyak $5 \%$, TNI dan POLRI sebanyak $3 \%$, dan pegawai BUMN sebanyak $1 \%{ }^{5}$

Data diatas menunjukkan bahwa persentase peserta mandiri cukup besar baik secara nasional, provinsi dan kota. Tingkat wilayah Provinsi Sumatera Barat, Kota Solok memiliki kolektabilitas iuran yaitu $31,07 \% .^{5}$

Berdasarkan studi pendahuluan yang dilakukan oleh penulis, saat ini terjadi fenomena di masyarakat khususnya peserta mandiri JKN, mendaftarkan dirinya dan keluarga sebagai peserta JKN hanya saat ingin berobat dan membutuhkan pelayanan kesehatan. Hal ini dapat dilihat dari jumlah peserta mandiri menunggak di Kota Solok yaitu 4.979 jiwa atau sejumlah $69 \%$ dari peserta mandiri terdaftar, dengan rincian kelas I sejumlah $21,1 \%$, kelas II sejumlah $18 \%$, dan kelas III sejumlah $60,9 \%$ dari peserta mandiri menunggak. $^{5}$

Putra (2015) menemukan bahwa faktor-faktor yang berpengaruh secara signifikan terhadap kepatuhan peserta mandiri adalah pengetahuan, pendapatan, cara pembayaran iuran, perilaku petugas dan persepsi risiko. ${ }^{6}$ Penelitian lainnya dari Pratiwi (2016) mengidentifikasi faktor-faktor yang mempengaruhi kepatuhan peserta mandiri BPJS Kesehatan dalam pembayaran iuran adalah tempat pembayaran iuran, pendapatan, pengeluaran, dan motivasi peserta mandiri $\mathrm{JKN}^{7}$

Berbagai upaya untuk meningkatkan kolektibilitas iuran khususnya segmen peserta mandiri telah dilakukan oleh BPJS Kesehatan, antara lain pembayaran dapat dilakukan di kantor Bank Mandiri/ BNI/ BRI/ BTN, ATM, internet banking, SMS gateway, surat tagihan kepada peserta, bekerjasama dengan channel PPOB (Payment Point Online Bank), tersedianya mesin EDC (Electronic Data Capture) di Kantor Cabang BPJS Kesehatan. Namun, upaya ini belum mampu meningkatkan kolektibilitas iuran secara signifikan. $^{8}$

Berdasarkan hal tersebut penulis tertarik untuk mengidentifiaksi faktor-faktor yang mempengaruhi kepatuhan peserta mandiri dalam pembayaran iuran Program JKN di Kota Solok.

\section{METODE}

Penelitian ini menggunakan desain cross sectional untuk mengidentifikasi faktor-faktor yang mempengaruhi kepatuhan peserta mandiri dalam pembayaran iuran program JKN. Populasi pada penelitian ini adalah seluruh peserta mandiri di Kota Solok pada bulan April 2016 dampai dengan bulan April 2017. Perhitungan jumlah sampel menggunakan rumus estimasi proporsi untuk pendugaan proporsi tunggal dan didapatkan jumlah sampel 105 orang. Teknik pengambilan sampel pada penelitian ini adalah dengan menggunakan teknik stratified random sampling, artinya pemilihan sampel dengan terlebih dahulu populasi dibagi kedalam strata (tingkat kelas iuran) dan selanjutnya pada masing-masing tingkat kelas iuran menggunakan simple random sampling. ${ }^{9}$ Pengambilan sample peserta secara acak dengan jumlah yang proposional pada tiap kelas iuran.

Variabel dependen dalam penelitian ini yaitu kepatuhan, sedangkan variabel independen yaitu pendidikan, pengetahuan, jarak tempat pembayaran iuran, pendapatan, jumlah anggota keluarga, persepsi terhadap pelayanan kesehatan dan, persepsi risiko. Pengambilan informasi mengenai variabel dependen dan variabel independen dilakukan dengan menggunakan kuesioner yang telah divalidasi.

\section{HASIL}

\section{Karakteristik Responden}

Tabel 1. Karakteristik responden

\begin{tabular}{lcc}
\hline \multicolumn{1}{c}{ Variabel } & Frekuensi (f) & $\%$ \\
\hline Jenis Kelamin & 48 & 45.7 \\
Laki-laki & 57 & 54.3 \\
Perempuan & & \\
Pendidikan & 12 & 11.4 \\
Tamat SD & 17 & 16.2 \\
Tamat SMP & 63 & 60.0 \\
Tamat SMA & 13 & 12.4 \\
Tamat PT & & \\
Pekerjaan & 26 & 24.8 \\
Tidak Bekerja & 79 & 75.2 \\
Bekerja & & \\
Status Perkawinan & 23 & 21.9 \\
Belum Menikah & 70 & 66.7 \\
Menikah & 12 & 11.4 \\
Janda/Duda & & \\
\hline
\end{tabular}


Tabel 1 menunjukkan bahwa sebagian besar responden adalah perempuan yaitu 57 orang (54,3\%). Lebih dari separoh pendidikan responden adalah tamat SMA dengan jumlah sebanyak 63 orang (60\%). Status pekerjaan responden sebagian besar adalah sudah bekerja dengan jumlah sebanyak 79 orang $(75,2 \%)$ dan status perkawinan responden sebagian besar adalah sudah menikah (66,7\%).

\section{Distribusi Frekuensi Responden Berdasarkan kepatuhan Pembayaran Iuran Program JKN dan Faktor yang Mempengaruhi}

Tabel 2. Distribusi frekuensi responden berdasarkan kepatuhan pembayaran iuran program JKN dan faktor yang mempengaruhi

\begin{tabular}{|c|c|c|}
\hline Variabel & Frekuensi (f) & $\%$ \\
\hline \multicolumn{3}{|l|}{ Kepatuhan } \\
\hline Tidak Patuh & 74 & 70.5 \\
\hline Patuh & 31 & 29.5 \\
\hline \multicolumn{3}{|l|}{ Pendidikan } \\
\hline Rendah & 29 & 27.6 \\
\hline Tinggi & 76 & 72.4 \\
\hline \multicolumn{3}{|l|}{ Pengetahuan } \\
\hline Rendah & 40 & 38.1 \\
\hline Tinggi & 65 & 61.9 \\
\hline \multicolumn{3}{|c|}{ Jarak Menuju Tempat } \\
\hline \multicolumn{3}{|l|}{ Pembayaran luran } \\
\hline Jauh & 17 & 16.2 \\
\hline Dekat & 88 & 83.8 \\
\hline \multicolumn{3}{|l|}{ Pendapatan } \\
\hline Tinggi & 52 & 49.5 \\
\hline Rendah & 53 & 50.5 \\
\hline \multicolumn{3}{|c|}{ Jumlah Anggota Keluarga } \\
\hline \multicolumn{3}{|l|}{ yang Ditanggung } \\
\hline$>5$ orang & 17 & 16.2 \\
\hline$\leq 5$ orang & 88 & 83.8 \\
\hline \multicolumn{3}{|l|}{ Persepsi Terhadap } \\
\hline \multicolumn{3}{|c|}{ Pelayanan Kesehatan } \\
\hline Buruk & 58 & 55.2 \\
\hline Baik & 47 & 44.8 \\
\hline \multicolumn{3}{|l|}{ Persepsi Risiko } \\
\hline Buruk & 41 & 39.0 \\
\hline Baik & 64 & 61.0 \\
\hline
\end{tabular}

Tabel 2 menunjukkan bahwa sebagian besar peserta mandiri yaitu sebanyak 74 orang (70,5\%) pernah menunggak iuran 2 bulan atau lebih dalam periode dari bulan April tahun 2016 sampai dengan bulan April tahun 2017. Hasil ini menunjukkan bahwa kurang dari separoh peserta mandiri rutin melakukan pembayaran iuran setiap bulannya dari bulan April tahun 2016 sampai dengan bulan April tahun 2017. Sebagian besar responden (72,4\%) memiliki tingkat pendidikan tinggi yaitu menamatkan pendidikan SMA dan S1. Sebagian besar responden (61,9\%) mempunyai tingkat pengetahuan yang tinggi mengenai Program JKN. Sebagian besar responden (83,8\%) memiliki jarak rumah dekat menuju tempat pembayaran iuran, yaitu kurang dari $5 \mathrm{~km}$ dari tempat pembayaran. Tingkat pendapatan responden yang tergolong tinggi, yaitu diatas Rp.1.949.285 sebanyak 53 orang $(50,5 \%)$. Sebagian besar peserta mandiri $(83,8 \%)$ memiliki jumlah anggota keluarga yang dibayarkan iuran program JKN setiap bulan $\leq 5$ orang. Sebagian besar $(55,2 \%)$ peserta mandiri memiliki persepsi buruk terhadap pelayanan kesehatan dan $(61,0 \%)$ peserta mandiri memiliki persepsi baik terhadap risiko.

\section{Faktor-Faktor yang Mempengaruhi Kepatuhan Peserta Mandiri Dalam Pembayaran luran JKN}

Data mengenai faktor yang berhubungan dengan kepatuhan responden dalam pembayaran iuran program JKN disajikan pada Tabel 3. 
Tabel 3. Hubungan antara Pendidikan, Pengetahuan, Jarak, Pendapatan, Jumlah Anggota Keluarga, Persepsi Pelayanan Kesehatan, dan Persepsi Risiko dengan Kepatuhan Peserta Mandiri dalam Pembayaran luran Program JKN di Kota Solok Tahun 2017

\begin{tabular}{|c|c|c|c|c|c|c|}
\hline \multirow{3}{*}{ Variabel } & \multicolumn{4}{|c|}{ Kepatuhan } & \multirow{3}{*}{$\begin{array}{c}\text { OR } \\
95 \% \mathrm{Cl}\end{array}$} & \multirow{3}{*}{ p } \\
\hline & \multicolumn{2}{|c|}{$\begin{array}{l}\text { Tidak } \\
\text { Patuh }\end{array}$} & \multicolumn{2}{|c|}{ Patuh } & & \\
\hline & $f$ & $\%$ & $f$ & $\%$ & & \\
\hline \multicolumn{7}{|l|}{ Tingkat } \\
\hline \multicolumn{7}{|l|}{ Pendidikan } \\
\hline \multirow[t]{2}{*}{ Rendah } & 19 & 65. & 10 & 34. & - & 0.564 \\
\hline & & 5 & & 5 & & \\
\hline \multirow[t]{2}{*}{ Tinggi } & 55 & 72. & 21 & 27. & & \\
\hline & & 4 & & 6 & & \\
\hline \multicolumn{7}{|l|}{ Tingkat } \\
\hline \multicolumn{7}{|c|}{ Pengetahuan } \\
\hline \multirow[t]{2}{*}{ Rendah } & 34 & 85. & 6 & 15. & 3.542 & 0.019 \\
\hline & & 0 & & 0 & & \\
\hline \multirow[t]{2}{*}{ Tinggi } & 40 & 61. & 25 & 38. & (1.301- & \\
\hline & & 5 & & 5 & $9.641)$ & \\
\hline \multicolumn{7}{|c|}{ Jarak Menuju } \\
\hline \multicolumn{7}{|c|}{ Tempat } \\
\hline \multicolumn{7}{|l|}{ Pembayaran } \\
\hline \multicolumn{7}{|l|}{ luran } \\
\hline \multirow[t]{2}{*}{ Jauh } & 11 & 64. & 6 & 35. & - & 0.780 \\
\hline & & 7 & & 3 & & \\
\hline \multirow[t]{2}{*}{ Dekat } & 63 & 71. & 25 & 28. & & \\
\hline & & 6 & & 4 & & \\
\hline \multicolumn{7}{|l|}{ Pendapatan } \\
\hline \multirow[t]{2}{*}{ Rendah } & 42 & 80. & 10 & 19. & 2.76 & 0.038 \\
\hline & & 8 & & 2 & & \\
\hline Tinggi & 32 & 60. & 21 & 39. & $(1.141-$ & \\
\hline & & 4 & & 6 & $6.667)$ & \\
\hline Jumlah & & & & & & \\
\hline Anggota & & & & & & \\
\hline Keluarga & & & & & & \\
\hline yang & & & & & & \\
\hline Ditanggung & & & & & & \\
\hline$>5$ orang & 14 & 82. & 3 & 17. & 2.178 & 0.378 \\
\hline & & 4 & & 6 & & \\
\hline$\leq 5$ orang & 60 & 68. & 28 & 31. & $(0.579-$ & \\
\hline & & 2 & & 8 & $6.159)$ & \\
\hline Persepsi & & & & & & \\
\hline terhadap & & & & & & \\
\hline Pelayanan & & & & & & \\
\hline Kesehatan & & & & & & \\
\hline Buruk & 46 & 79. & 12 & 20. & 2.601 & 0.047 \\
\hline & & 3 & & 7 & & \\
\hline Baik & 28 & 59. & 19 & 40. & (1.099- & \\
\hline & & 6 & & 4 & $6.159)$ & \\
\hline Persepsi & & & & & & \\
\hline Risiko & & & & & & \\
\hline
\end{tabular}

\begin{tabular}{|c|c|c|c|c|c|c|}
\hline \multirow{4}{*}{ Variabel } & \multicolumn{4}{|c|}{ Kepatuhan } & \multirow{4}{*}{$\begin{array}{c}\text { OR } \\
95 \% \mathrm{Cl}\end{array}$} & \multirow{4}{*}{$p$} \\
\hline & \multirow{2}{*}{\multicolumn{2}{|c|}{$\begin{array}{l}\text { Tidak } \\
\text { Patuh }\end{array}$}} & \multirow{2}{*}{\multicolumn{2}{|c|}{ Patuh }} & & \\
\hline & & & & & & \\
\hline & $f$ & $\%$ & $f$ & $\%$ & & \\
\hline \multirow[t]{2}{*}{ Baik } & 34 & 82. & 7 & 17. & 2.914 & 0.043 \\
\hline & & 9 & & 1 & & \\
\hline \multirow[t]{2}{*}{ Buruk } & 40 & 62. & 24 & 37. & (1.118- & \\
\hline & & 5 & & 5 & $7.596)$ & \\
\hline
\end{tabular}

Tabel 3 menunjukkan bahwa terdapat hubungan yang bermakna antara pengetahuan, pendapatan, persepsi terhadap pelayanan kesehatan dan persepsi risiko dengan kepatuhan peserta mandiri dalam pembayaran iuran program JKN. Persentase tingkat kepatuhan lebih tinggi pada responden dengan tingkat pengetahuan tinggi dibanding dengan responden tingkat pengetahuan rendah. Hasil uji chi square didapatkan nilai $\mathrm{p}=0,019 \quad(\mathrm{p}<0,05)$ artinya ada hubungan yang signifikan antara tingkat pengetahuan dengan kepatuhan.

Persentase tingkat kepatuhan lebih tinggi pada responden dengan tingkat pendapatan tinggi dibanding dengan responden tingkat pendapatan rendah. Hasil uji Chi-square didapatkan nilai $\mathrm{p}=0,038$ $(p<0,05)$ yang artinya ada hubungan yang signifikan antara pendapatan dengan kepatuhan peserta mandiri dalam pembayaran iuran program JKN.

Tingkat kepatuhan lebih tinggi pada responden dengan persepsi baik terhadap pelayanan kesehatan dibanding dengan responden persepsi buruk terhadap pelayanan kesehatan. Hasil uji chi square didapatkan nilai $p=0,047 \quad(p<0,05)$ yang artinya ada hubungan yang signifikan antara persepsi terhadap pelayanan kesehatan dengan kepatuhan peserta mandiri dalam pembayaran iuran program JKN.

Persentase tingkat kepatuhan lebih tinggi pada responden dengan persepsi risiko baik dibanding dengan responden persepsi risiko buruk. Hasi uji chi square didapatkan nilai $p=0,043(p<0,05)$ yang artinya ada hubungan yang signifikan antara persepsi risiko dengan kepatuhan peserta mandiri dalam pembayaran iuran program JKN.

Jarak menuju tempat pembayaran iuran dan jumlah anggota keluarga yang ditanggung tidak terdapat hubungan yang signifikan dengan kepatuhan peserta mandiri dalam pembayaran iuran program JKN. Persentase tingkat kepatuhan lebih tinggi pada responden dengan tingkat pendidikan rendah 
dibanding dengan responden tingkat pendidikan tinggi. Hasil uji chi square didapatkan nilai $p=0,564(p>0,05)$ artinya tidak ada hubungan yang signifikan antara tingkat pendidikan dengan kepatuhan.

Persentase tingkat kepatuhan lebih tinggi pada responden dengan jarak menuju tempat pembayaran iuran jauh dibanding dengan responden dengan jarak menuju tempat pembayaran iuran dekat. Hasil uji chi square didapatkan nilai $p=0,780(p>0,05)$ artinya tidak ada hubungan yang signifikan antara jarak menuju tempat pembayaran iuran dengan kepatuhan.

Persentase tingkat kepatuhan lebih tinggi pada responden dengan jumlah anggota keluarga yang ditanggung $\leq 5$ dibanding dengan responden dengan jumlah anggota keluarga yang ditanggung $>5$ orang. Hasil uji chi square didapatkan nilai $p=0,378(p>0,05)$ artinya tidak ada hubungan yang signifikan antara jumlah anggota keluarga yang ditanggung dengan kepatuhan.

Penghitungan Odd Ratio (OR) dilakukan untuk fakto-faktor yang menunjukkan hubungan signifikan. Untuk tingkat pengetahuan diperoleh nilai $\mathrm{OR}=3,542$ yang artinya responden dengan tingkat pengetahuan tinggi mempunyai peluang 3,54 kali untuk melakukan pembayaran iuran tepat waktu atau tidak menunggak daripada responden yang berpengetahuan rendah. Untuk tingkat pendapatan diperoleh nilai $\mathrm{OR}=2,756$ yang artinya responden berpendapatan tinggi mempunyai peluang 2,75 kali untuk pembayaran iuran tepat waktu atau tidak menunggak iuran daripada responden berpendapatan rendah. Selain itu, diperoleh nilai $O R=2,601$ untuk tingkat persepsi pelayanan, yang berarti bahwa responden yang memiliki persepsi baik terhadap pelayanan kesehatan mempunyai peluang 2,60 kali untuk melakukan pembayaran iuran tepat waktu atau tidak menunggak daripada responden yang memiliki persepsi buruk terhadap pelayanan kesehatan. Selanjutnya diperoleh nilai $\mathrm{OR}=2,914$ untuk tingkat persepsi risiko yang berarti bahwa responden dengan persepsi baik terhadap risiko mempunyai peluang 2,91 kali untuk melakukan pembayaran iuran tepat waktu atau tidak menunggak dari pada responden yang memiliki persepsi buruk terhadap risiko.

\section{PEMBAHASAN}

\section{Hubungan Tingkat Pendidikan dengan Kepatuhan Peserta Mandiri dalam Pembayaran luran JKN}

Persentase tingkat kepatuhan peserta mandiri dalam membayar iuran program JKN lebih tinggi pada kelompok peserta yang berpendidikan rendah $(34,5 \%)$ dibandingkan dengan kelompok peserta yang berpendidikan tinggi (27,6\%). Hasil uji statistik menunjukkan bahwa tidak ada perbedaan bermakna antara dua kelompok peserta ini dalam kepatuhan pembayaran iuran program JKN $(p=0,564)$

Hasil ini sesuai dengan hasil penelitian Putra (2015) di Kabupaten Mempawah Kalimantan Barat, bahwa secara uji statistik tidak terdapat hubungan yang bermakna antara pendidikan dengan kepatuhan peserta mandiri dalam membayar iuran BPJS Kesehatan secara rutin. ${ }^{6}$ Sebaliknya hasil penelitian ini berbeda dengan hasil penelitian yang dilakukan oleh Ruby et al (2017) bahwa ada hubungan yang bermakna antara pendidikan dengan kepatuhan peserta membayar iuran. ${ }^{10}$

Pendidikan merupakan suatu usaha kegiatan yang dijalankan dengan sengaja teratur dan berencana untuk mengembangkan potensi diri. ${ }^{11}$ Tingkat pendidikan seseorang dalam mengambil suatu keputusan tentang berbagai hal. Pendidikan dapat membuat seseorang menjadi lebih kritis terhadap sesuatu hal yang diamati. Seseorang yang berpendidikan lebih tinggi akan mempunyai pengetahuan luas dibandingkan tingkat pendidikan lebih rendah. ${ }^{12}$

Sebagian besar latar belakang pendidikan dari peserta mandiri Kota Solok adalah SMA dengan kategori tingkat pendidikan tinggi. Tingkat pendidikan tinggi ini membuat mereka lebih kritis dan berpengetahuan lebih luas serta mempunyai harapan lebih tinggi terhadap kualitas pelayanan. Ketika mereka memiliki persepsi pelayanan yang buruk, hal ini dapat mempengaruhi keputusan mereka dalam pembayaran iuran JKN. Oleh karena itu dapat dipahami kenapa persentase kepatuhan membayar iuran JKN lebih rendah pada kelompok peserta dengan tingkat pendidikan lebih tinggi, walaupun secara statistik tingkat pendidikan tidak signifikan berpengaruh terhadap kepatuhan. 


\section{Hubungan Tingkat Pengetahuan dengan Kepatuhan Peserta Mandiri dalam Pembayaran luran JKN}

Persentase tingkat kepatuhan peserta mandiri dalam membayar iuran program JKN lebih tinggi pada kelompok peserta dengan tingkat pengetahuan tinggi $(38,5 \%)$ dibandingkan dengan kelompok peserta tingkat pengetahuan rendah (15,0\%). Hasil uji statistik menunjukkan bahwa ada hubungan signifikan antara tingkat pengetahuan dengan kepatuhan pembayaran iuran program JKN $(p=0,019)$.

Hasil ini sesuai dengan penelitian yang dilakukan Mokolomban et al (2018) di Wilayah Kerja Puskesmas Ranotana Weru Kota Manado adanya hubungan yang bermakna antara pengetahuan dengan kepatuhan membayar iuran JKN Mandiri. ${ }^{16}$

Menurut Lawrence Green dalam Priyoto (2014) salah satu faktor yang mempengaruhi perilaku adalah faktor predisposisi, yang merupakan faktor yang mempermudah terjadinya perilaku dan berasal dari dalam diri individu, seperti pengetahuan. ${ }^{13}$ Salah satu faktor yang mempengaruhi pengetahuan peserta mandiri adalah informasi. Informasi yang semakin sering diberikan kepada peserta mandiri akan semakin baik dan akan mempengaruhi tingkat pengetahuan peserta mandiri. Informasi tersebut dapat disampaikan melalui buku pedoman, media massa seperti majalah, koran, ataupun televisi, saling bertukar informasi atau pengalaman, dan juga dari internet. Dari sumber informasi yang disediakan oleh BPJS Kesehatan, peserta mandiri program JKN dapat belajar dan memperoleh informasi lebih banyak sehingga pengetahuannya akan bertambah. Informasi yang telah disediakan oleh BPJS Kesehatan Cabang Solok antara lain spanduk yang terpasang di kantor cabang dan fasilitas kesehatan, poster dan leaflet yang ada di kantor cabang dan kanal pembayaran, iklan di radio dan televisi.

\section{Hubungan Jarak Tempuh Tempat Pembayaran luran dengan Kepatuhan Peserta Mandiri dalam Pembayaran luran JKN}

Persentase tingkat kepatuhan peserta mandiri dalam membayar iuran program JKN lebih tinggi pada kelompok peserta yang memiliki jarak tempuh tempat pembayaran iuran jauh (35,3\%) dibandingkan dengan kelompok peserta mandiri yang memiliki jarak tempuh tempat pembayaran iuran dekat $(28,4 \%)$. Hasil uji statistik menunjukkan tidak ada hubungan yang signifikan antara jarak tempuh menuju tempat pembayaran iuran dengan kepatuhan pembayaran iuran program JKN $(p=0,780)$.

Hasil ini sesuai dengan penelitian Putra (2015) di Kabupaten Mempawah Kalimantan Barat dengan $p=$ 0,701 bahwa kepatuhan membayar iuran tidak ada hubungan dengan jarak tempat tinggal responden. ${ }^{6}$ Sebaliknya berbeda dengan hasil penelitian yang dilakukan Muthalib (2018) di Kabupaten Nunukan bahwa jarak menuju tempat pembayaran iuran/ lokasi geografis tempat pembayaran iuran memiliki hubungan signifikan terhadap kepatuhan peserta mandiri membayar iuran program JKN. ${ }^{14}$

Kondisi geografis Kota Solok yang tergolong tidak terlalu luas dan memiliki dua kecamatan, dengan sebelas kelurahan. ${ }^{15}$ Kondisi ini menunjukkan bahwa seluruh daerah di Kota Solok masih dapat diakses dengan baik oleh peserta mandiri. Kanal-kanal pembayaran yang tersedia seperti pembayaran melalui interet banking dapat diakses langsung bagi peserta mandiri yang menggunakan smartphone. Walaupun beberapa daerah tergolong jauh dari tempat pembayaran iuran, namun jasa transportasi berupa ojek sepeda motor juga memberikan kemudahan akses bagi peserta mandiri untuk pergi ke kanal-kanal pembayaran iuran.

\section{Hubungan Tingkat Pendapatan dengan Kepatuhan Peserta Mandiri dalam Pembayaran luran JKN}

Pesentase tingkat kepatuhan peserta mandiri dalam membayar uran program JKN lebih tinggi pada kelompok peserta dengan tingkat pendapatan tinggi $(39,6 \%)$ dibandingkan dengan kelompok peserta tingkat pendapatan rendah $(19,2 \%)$. Hasil uji statistik menunjukkan bahwa ada hubungan antara tingkat pendapatan dengan kepatuhan pembayaran iuran program JKN $(p=0,038)$.

Hasil ini sesuai dengan hasil penelitian yang dilakukan oleh Rismawati et al (2017) di wilayah kerja Puskesmas Batalaiworu, hasil uji statistik dengan $p=$ 0,023 yang artinya bahwa terdapat hubungan antara 
pendapatan dengan kepatuhan peserta dalam membayar iuran BPJS mandiri. ${ }^{17}$ Sesuai juga dengan hasil penelitian yang dilakukan oleh Zulfa et al (2019) bahwa tingkat pendapatan memiliki hubungan dengan kepatuhan peserta mandiri dalam pembayaran iuran. ${ }^{18}$

Pendapatan seseorang memegang peranan penting tingginya kesadaran seseorang terhadap keteraturan dalam membayar iuran Jaminan Kesehatan Nasional (JKN). Pendapatan yang rendah mampu menurunkan keteraturan masyarakat dalam membayar iuran Jaminan Kesehatan Nasional (JKN) karena masih banyak kebutuhan yang harus dipenuhi oleh keluarga sehingga tidak ada alokasi pendapatan yang digunakan peserta untuk membayar iuran tersebut. Pendapatan tinggi dan mempunyai tingkat kesejahteraan menengah keatas memiliki tingkat kepatuhan yang tinggi dalam membayar iuran Jaminan Kesehatan Nasional. ${ }^{4}$

Peserta mandiri dengan pendapatan rendah, lebih memprioritaskan pendapatannya untuk memenuhi kebutuhan hidup sehari-hari yang bersifat rutin, seperti biaya makan, biaya pendidikan, pembayaran listrik dan air dan biaya lainnya, sedangkan untuk biaya kesehatan, peserta mandiri cenderung belum memprioritaskan dikarenakan masih dalam kondisi sehat. Sebaliknya, peserta mandiri dengan pendapatan tinggi, selain mampu mengalokasi pendapatannya untuk kebutuhan sehari-hari juga mampu untuk membayar biaya kesehatan sehingga dapat melakukan pembayaran iuran rutin setiap bulannya.

\section{Hubungan Jumlah Keluarga yang Ditanggung dengan Kepatuhan Peserta Mandiri dalam Pembayaran luran JKN}

Persentase tingkat kepatuhan peserta mandiri dalam membayar iuran program JKN lebih tinggi pada kelompok dengan jumlah anggota keluarga $\leq 5$ orang $(31,8 \%)$ dibandingkan dengan kelompok peserta dengan jumlah anggota keluarga $>5$ orang $(17,6 \%)$. Namun, hasil uji statistik menunjukkan tidak ada hubungan yang signifikan antara jumlah anggota keluarga yang ditanggung dengan kepatuhan pembayaran iuran program JKN $(p=0,378)$.
Hasil ini sejalan dengan Putra (2015) bahwa rerata besaran keluarga untuk yang ada tunggakan sama dengan yang tidak ada berarti tidak ada perbedaan yang signifikan besaran keluarga antara yang ada tunggakan dengan tidak ada tunggakan $p=$ $0,540(>0,05){ }^{6}$ Sebaliknya, hal ini tidak sejalan dengan penelitian yang dilakukan oleh Zulfa et al (2018) bahwa pendaftaran dan pembayaran seluruh anggota keluarga (sistem pembayaran kolektif) memiliki hubungan dengan kepatuhan peserta mandiri dalam pembayaran iuran. ${ }^{18}$

Unsur jumlah anggota keluarga memang menjadi aspek yang berperan dan tak dapat diabaikan. Semakin banyak jumlah anggota keluarga, akan semakin banyak pula jumlah iuran yang harus dibayarkan karena pembayaran yang bersifat kolektif. Secara otomatis, akan semakin meningkat pula alokasi dana dari penghasilan keluarga per bulan yang harus disediakan untuk pembayaran iuran BPJS Kesehatan. ${ }^{19}$

Saat ini masih ditemukan peserta mandiri yang mendaftarkan anggota keluarganya pada saat sakit dan apabila sudah sehat maka kepatuhan membayar iuran secara rutin diabaikan. Perubahan aturan dari BPJS Kesehatan bahwa pendaftaran peserta harus secara kolektif anggota keluarga dalam satu kartu keluarga, membuat jumlah anggota keluarga terdaftar menjadi salah satu daktor yang tidak dapat diabaikan. Hal ini dapat terlihat dari hasil penelitian kami bahwa persentase tingkat kepatuhan peserta mandiri dalam membayar iuran program JKN lebih tinggi pada kelompok dengan jumlah anggota keluarga $\leq 5$ orang $(31,8 \%)$ dibandingkan dengan kelompok peserta denan jumlah anggota keluarga > 5 orang (17,6\%), walaupun tidak terdapat perbedaan yang signifikan secara statisti antar dua kelompok ini.

\section{Hubungan Persepsi Terhadap Pelayanan Kesehatan dengan Kepatuhan Peserta Mandiri dalam Pembayaran luran JKN}

Persentase tingkat kepatuhan peserta mandiri dalam membayar iuran program JKN lebih tinggi pada kelompok peserta yang memiliki persepsi baik terhadap pelayanan kesehatan (40,4\%) dibandingkan 
dengan kelompok peserta mandiri dengan persepsi buruk terhadap pelayanan kesehatan (20,7\%). Hasil uji statistik menunjukkan bahwa ada hubungan bermakna antara persepsi terhadap pelayanan kesehatan dengan kepatuhan pembayaran iuran program JKN $(p=0,047)$.

Hasil penelitian ini sesuai dengan Pratiwi (2016) bahwa faktor-faktor penghambat kepatuhan pembayaran iuran berdasarkan persepsi peserta salah satunya yaitu motivasi yang berhubungan dengan ketidakpuasan akan kualitas layanan kesehatan yang diterima dengan menggunakan BPJS. ${ }^{7}$ Sesuai juga dengan hasil penelitian Rismawati et al (2017) di Wilayah Kerja Puskesmas Batalaiwaro Kabupaten Muna, bahwa persepsi peserta mandiri terhadap pelayanan kesehatan program JKN berhubungan dengan kepatuhan membayaran iuran BPJS mandiri. ${ }^{17}$

Persepsi merupakan suatu proses yang diawali oleh rangsangan yang diterima dari luar yang kemudian diorganisasikan dan diinterpretasikan sehingga menimbulkan suatu pemahaman. ${ }^{20}$ Persepsi terhadap pelayanan kesehatan merupakan perbandingan antara harapan peserta mandiri terkait pelayanan kesehatan dengan kenyataan pelayanan kesehatan yang diterima. Pembentukan persepsi sangat dipengaruhi oleh informasi atau rangsangan yang pertama kali diperolehnya.

Persepsi peserta program JKN terhadap pelayanan kesehatan yang bekerja sama dengan BPJS Kesehatan dapat mempengaruhi keinginan masyarakat untuk membayar iuran program JKN. Pengalaman baik yang dirasakan oleh peserta dapat mempengaruhi peserta untuk tetap membayarkan iuran secara rutin, sebaliknya pengalaman buruk yang dirasakan oleh peserta akan mempengaruhi peserta untuk tidak melakukan pembayaran iuran. Pelayanan kesehatan yang didapatkan kurang baik, seperti adanya tambahan biaya obat yang dialami peserta dan tidak ada penjelasan mendetail yang diberikan kepada peserta, kamar rawat inap yang tidak sesuai dengan hak kelas rawatan peserta, antrian yang panjang dan perbedaan perlakuan antara peserta JKN dengan pasien umum yang dialami oleh peserta.

\section{Hubungan Persepsi Terhadap Risiko dengan Kepatuhan Peserta Mandiri dalam Pembayaran luran JKN}

Persentase tingkat kepatuhan peserta mandiri dalam membayar iuran program JKN lebih tinggi pada kelompok peserta yang memiliki persepsi risiko baik $(37,5 \%)$ dibandingkan dengan kelompok peserta mandiri yang persepsi risiko buruk (17,1\%). Hasil uji statistik menunjukkan bahwa ada hubungan bermakna antara persepsi terhadap risiko kesehatan dengan kepatuhan pembayaran iuran program JKN $(p=0,043)$.

Hasil ini sesuai dengan hasil penelitian Putra (2015) di Kecamatan Mempawah Hilir dan Timur Kabupaten Mempawah Kalimantan Barat bahwa salah satu faktor yang berpengaruh secara signifikan terhadap kepatuhan peserta mandiri BPJS Kesehatan adalah faktor pengetahuan, pendapatan, cara pembayaran, perilaku petugas, dan persepsi risiko. ${ }^{6}$

Menurut Notoatmodjo (2010), seseorang yang memiliki penyakit tertentu baik yang diderita orang tersebut maupun anggota keluarganya akan mempengaruhi seseorang dalam perubahan perilaku hidup sehat. Berpartisipasi dalam asuransi kesehatan merupakan salah satu cara atau sikap seseorang terhadap perilaku kesehatannya sendiri. Peningkatan pembiayaan JKN khususnya untuk penyakit katastropik (jantung, stroke, gagal ginjal, diabetes dan lain-lain) pada tahun 2014 yaitu 8,7 triliun dan meningkat pada tahun 2018 menjadi 20,4 triliun. $^{12}$

Peserta yang memiliki riwayat penyakit lebih patuh membayar iuran dikarenakan peserta ingin mengurangi beban biaya terhadap risiko penyakit yang dimiliki, sedangkan peserta yang merasa dirinya tidak pernah sakit dan tidak pernah memanfaatkan pelayanan kesehatan akan berpeluang untuk terlambat membayarkan iuran program JKN. Upaya untuk meningkatkan kesehatan kesadaran masyarakat atau peserta mandiri program JKN khususnya adalah dengan memberikan informasi-informasi tentang pentingnya perlindungan risiko finansial yang tidak dapat dihindari apabila peserta sudah jatuh sakit. 


\section{SIMPULAN}

Faktor yang berhubungan signifikan dengan kepatuhan pembayaran iuran peserta mandiri program JKN BPJS Kesehatan di Kota Solok pada penelitian kami yaitu tingkat pengetahuan, pendapatan, persepsi terhadap pelayanan kesehatan dan risiko.

Faktor yang tidak memiliki hubungan yang signifikan adalah tingkat pendidikan, jarak tempuh tempat pembayaran iuran, dan jumlah tanggungan.

\section{SARAN}

BPJS Kesehatan Cabang Solok harus meningkatkan kuantitas dan kualitas sosialisasi untuk meningkatkan pengetahuan peserta tentang hak dan kewajiban peserta.

\section{UCAPAN TERIMA KASIH}

Terimaksih kepada BPJS Kesehatan Cabang Kota Solok, Dinas Sosial Kota dan semua pihak yang telah memberikan motivasi, bimbingan dan bantuan kepada penulis dalam menyelesaikan tulisan ini.

\section{DAFTAR PUSTAKA}

1. Undang-Undang Republik Indonesia Nomor 36 Tahun 2009 tentang Kesehatan.

2. Undang Undang Republik Indonesia Nomor 40 Tahun 2004 tentang Sistem Jaminan Nasional.

3. Thabrany $\mathrm{H}$. Dasar-dasar asuransi kesehatan. Jakarta: PAMJAKI; 2005.hlm.10-5.

4. BPJS Kesehatan. Info BPJS kesehatan edisi XXII. Jakarta: BPJS Kesehatan; 2016.

5. BPJS Kesehatan. Laporan kepesertaan tahun 2016. Jakarta: BPJS Kesehatan; 2016.

6. Putra R. Analisis faktor-faktor yang mempengaruhi kepatuhan peserta mandiri BPJS kesehatan dalam membayar iuran secara rutin di Kecamatan Mempawah Hilir dan Timur Kabupaten Mempawah Kalimantan Barat [tesis]. Depok: Fakultas Kesehatan Masyarakat, Universitas Indonesia; 2015.

7. Pratiwi AN. Faktor yang mempengaruhi keteraturan membayar iuran pada peserta jaminan kesehatan nasional (JKN) kategori peserta mandiri Kabupaten Jember [tesis]. Jember: Bagian
Administrasi dan Kebijakan Kesehatan, Fakultas Kesehatan Masyarakat, Universitas Jember; 2016.

8. BPJS Kesehatan. Peraturan BPJS kesehatan nomor 1 tahun 2015 tentang tata cara pendaftaran dan pembayaran iuran bagi peserta pekerja bukan penerima upah dan peserta bukan pekerja. Jakarta: BPJS Kesehatan; 2015.

9. Sugiyono. Metode penelitian kuantitatif dan kualitatif. Bandung: Alfabeta; 2014.hlm.43-7.

10. Ruby M, Srikandi D, Pujiyanti E, Sayekti MA, Siregar DRP, Andikashwari S, et al. A Collection model of health insurance constributions for informal sector members. INAHEA (e-Journal). 2017;1:242-7.

11. Undang Undang Republik Indonesia Nomor 20 Tahun 2003 tentang Sistem Pendidikan Nasional.

12. Notoatmodjo S. Promosi kesehatan dan ilmu perilaku. Jakarta: PT Rineka Cipta; 2010.hlm.14252.

13. Priyoto. Teori sikap dan perilaku dalam kesehatan. Yogyakarta: Nuha Medika; 2014.hlm.24-34.

14. Mutholib A. Implementasi kebijakan jaminan kesehatan nasional peserta bukan penerima bantuan iuran mandiri di Kabupaten Nunukan [tesis]. Jakarta: Fakultas Administrasi Bidang Minat Administrasi Publik, Universitas Terbuka Jakarta; 2018.

15. Diskominfo. Profil Kota Solok. Solok: Dinas Komunikasi dan Informatika Kota Solok. 2017 [ diakses 3 Maret 2018]. Tersedia dari: http://www.solokkota.go.id

16. Mokolomban C, Creisye KF, Grace EC. Faktorfaktor yang berhubungan dengan kepatuhan peserta mandiri dalam membayar iuran jaminan kesehatan nasional di wilayah kerja Puskesmas Ranotana Weru Kota Manado. Jurnal Kesehatan Masyarakat Universitas Sam Ratulangi. 2018;7(4): 4-9.

17. Rismawati, Lisnawaty, Jufri NN. Factors related with compliance paying of BPJS mandiri insurance. contribution in the working area of Batalaiworu Public Health Center In 2017. Jimkesmas Jurnal IImiah Mahasiswa Kesehatan Masyarakat (eJournal). 2017;2(8):ISSN 2502-731X. 
18. Zulfa A, Izza N, Aimanah IU. Participant collective payment system with class participation and monthly premium compliance of BPJS at Malang regency. Buletin Penelitian Sistem Kesehatan. 2019;22(1):44-53.

19. Munawar. Faktor yang berhubungan dengan pemanfaatan pelayanan kesehatan di Puskesmas Barrang Lompo Kota Makassar tahun 2017 [tesis]. Makassar: Fakultas Kesehatan Masyarakat, Universitas Hasanuddin; 2017.

20. Walgito B. Pengantar psikologi umum. Yogyakarta: CV Andi Offset; 2010.hlm.20-5. 